\title{
Erratum to: Osteogenic differentiation of dental pulp stem cells under the influence of three different materials
}

\author{
Sumaiah A. Ajlan ${ }^{1 *}$, Nahid Y. Ashri ${ }^{1}$, Abdullah M. Aldahmash ${ }^{2,3}$ and May S. Alnbaheen ${ }^{4}$
}

After publication of this work [1], the authors noticed that Figs. 1 and 4 are duplicated. The original version of this article was corrected. The publisher apologizes for any inconvenience caused.

The correct Fig. 1 is given below:

\begin{abstract}
Author details
'Department of Periodontics and Community Dentistry, College of Dentistry, King Saud University, PO box: 65506, Riyadh 11588, Saudi Arabia. ${ }^{2}$ Stem Cell Unit, Anatomy Department, Collage of Medicine, King Saud University, Riyadh, Saudi Arabia. ${ }^{3}$ Department of Endocrinology and Metabolism, Endocrine Research Laboratory (KMEB), Odense University Hospital \& University of Southern Denmark, Odense, Denmark. ${ }^{4}$ Dean of Preparatory Year, Saudi Electronic University, King Saud University, Riyadh, Saudi Arabia.
\end{abstract}

Received: 30 November 2015 Accepted: 9 March 2016

Published online: 22 March 2016

\section{References}

1. Ajlan SA, Ashri NY, Aldahmash AM, Alnbaheen MS. Osteogenic

differentiation of dental pulp stem cells under the influence of three

different materials. BMC Oral Health. 2015;15:132.

\footnotetext{
* Correspondence: dr-ajlan2006@hotmail.com

1 Department of Periodontics and Community Dentistry, College of Dentistry, King Saud University, PO box: 65506, Riyadh 11588, Saudi Arabia

Full list of author information is available at the end of the article
}

Submit your next manuscript to BioMed Central and we will help you at every step:

- We accept pre-submission inquiries

- Our selector tool helps you to find the most relevant journal

- We provide round the clock customer support

- Convenient online submission

- Thorough peer review

- Inclusion in PubMed and all major indexing services

- Maximum visibility for your research

Submit your manuscript at www.biomedcentral.com/submit
Biomed Central 


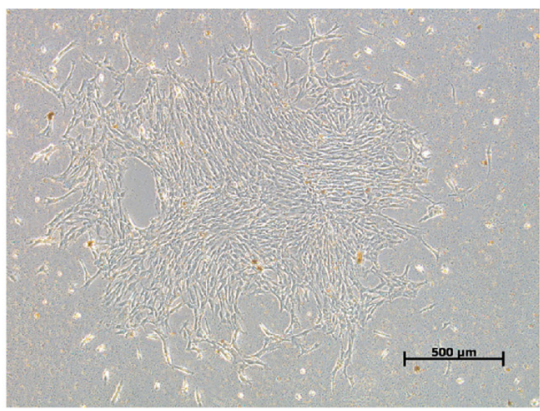

C

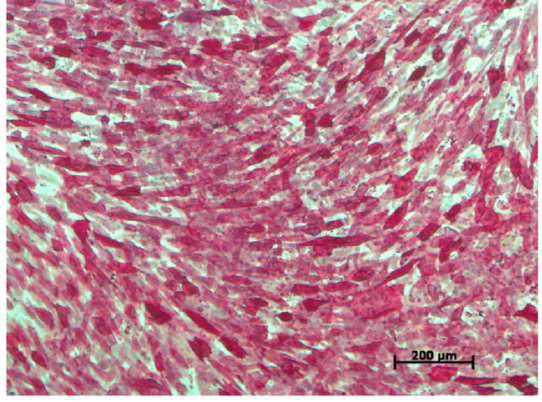

e

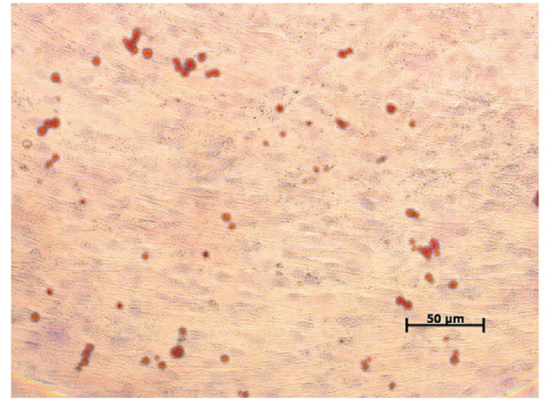

g
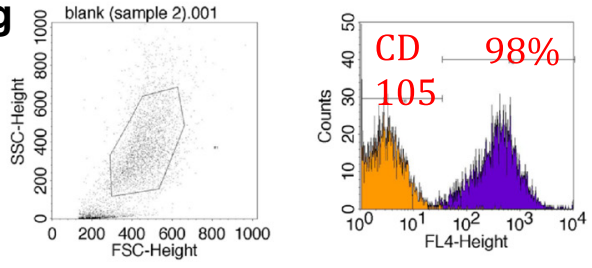

CD $2995 \%$

量: PE
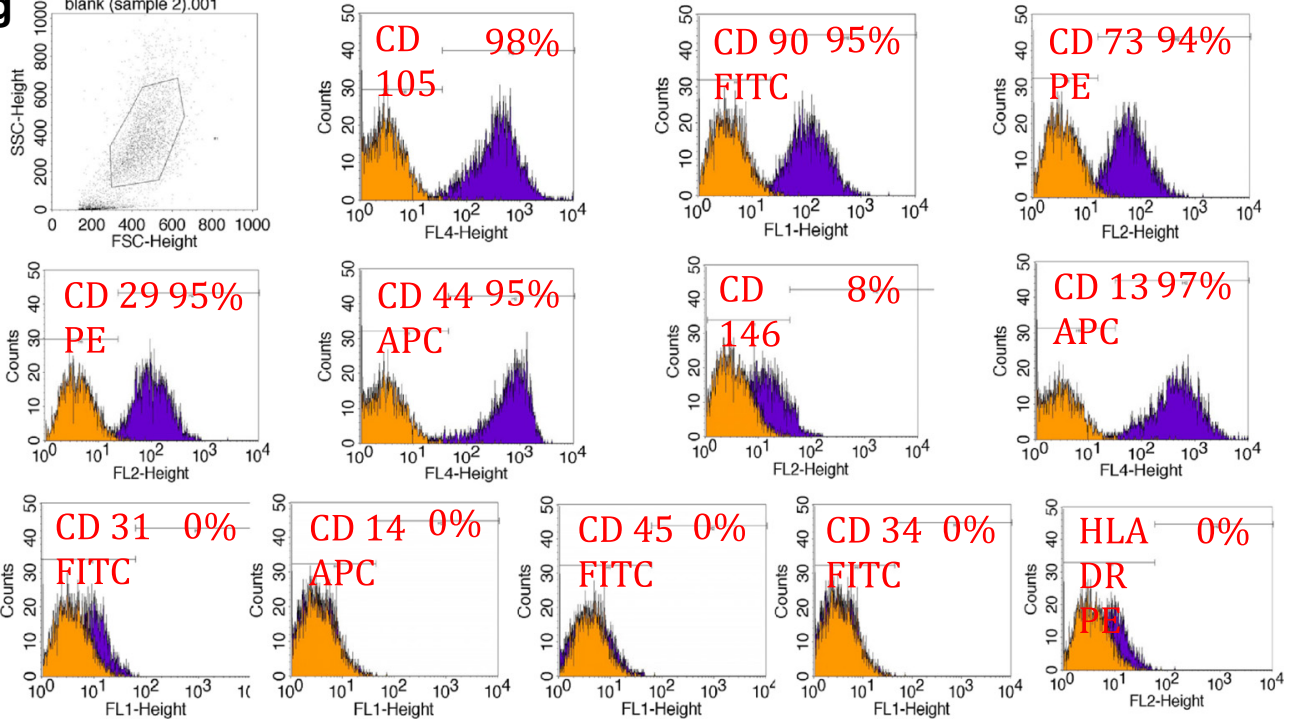

Fig. 1 Inverted light microscopic images showing (a) dental pulp mesenchymal stem cells at primary culture, Magnification $5 \times$. b Colony forming unit Fibroblast (CFU-F) magnification 5x, Alkaline phosphatase staining for DPSCs 14 days after osteoinduction (c) versus negative control (d), magnification 10x, and Oil red O staining for DPSCs 14 days after adipogenic induction (e) versus negative control (f), magnification 40X. (g) FACS analysis results of a representative dental pulp cell line 